\title{
Synthesis of potential dual binding site acetylcholinesterase inhibitors through an efficient solid phase approach based on the Mitsunobu reaction
}

\author{
Francesco Leonetti, ${ }^{a \dagger}$ Anna Cappa, ${ }^{a \dagger}$ Cristina Maccallini, $^{\mathrm{b}}$ and Angelo Carotti ${ }^{\mathrm{a}^{*}}$ \\ ${ }^{a}$ Dipartimento Farmaco-Chimico, Università di Bari, Via E. Orabona 4, I-70125 Bari \\ ${ }^{b}$ Dipartimento di Scienze del Farmaco, Università “G. D’Annunzio”, \\ Via dei Vestini, I-66100 Chieti \\ E-mail: carotti@farmchim.uniba.it
}

\section{In honor of Professor Vincenzo Tortorella on the occasion of his "Fuori Ruolo" status}

(received 12 Feb 04; accepted 29 Mar 04; published on the web 01 Apr 04)

\begin{abstract}
A solid phase synthesis of a number of monoamino and diamino derivatives as potential dual binding site AChE inhibitors was developed. Our synthetic protocol was characterized by a series of three consecutive Mitsunobu reactions. The loading of the first building block, a dimethylaminophenol, onto the brominated Wang resin was efficiently carried out with DIAD and $\mathrm{PPh}_{3}$ in THF, whereas the two subsequent Mitsunobu reactions, allowing the introduction of an aliphatic spacer linked to a second phenolic moiety, resulted in higher yields when performed with ADDP and $\mathrm{PBu}_{3}$ in $\mathrm{CH}_{2} \mathrm{Cl}_{2}$. The scheme adopted in this synthesis could allow an easy and straightforward entry to libraries of amines of the general formulae $\mathbf{A}$ and $\mathbf{B}$.
\end{abstract}

Keywords: Chemical library, solid phase synthesis, Mitsunobu reaction, acetycholinesterase inhibitors

\section{Introduction}

In the last decade combinatorial chemistry has represented the most promising approach to allow entry to a great number of biological targets arising from molecular biology and genomic studies. ${ }^{1}$ In fact, the possibility of synthesizing libraries of hundreds of compounds in a suitable scalable fashion has determined an epochal change in medicinal chemistry, especially in the fundamental processes of lead discovery and optimization. ${ }^{2}$ The positive impact that

\footnotetext{
${ }^{*}$ Corresponding author. Tel ++39-080-5442782; fax: ++39-080-5442230;

${ }^{\dagger}$ These authors contributed equally to this work.
} 
combinatorial chemistry has had in reducing the time necessary for the identification and optimization of leads, has favoured the development of suitable techniques and automated equipments to prepare libraries of compounds. ${ }^{3}$ In particular, two different approaches are currently followed for the preparation of libraries: the solid phase synthesis and the solid supported reagent-driven reactions. ${ }^{4-7}$

Following the pioneering work of Merrifield, ${ }^{8}$ the solid phase synthesis exploded in the 90's after the publication by Ellman and co-workers of the synthesis of a library of benzodiazepines that represented the first example of small organic molecules of pharmaceutical interest completely prepared on the solid phase. ${ }^{9}$ As witnessed by the huge number of papers published afterwards, combinatorial chemistry became an essential discipline in the field of medicinal chemistry both for academic institutions and pharmaceutical companies.

In this report we describe the design and the solid phase synthesis of a small library of compounds as potential inhibitors of acetylcholinesterase (AChE). AChE is a key enzyme involved in the termination of nervous signals through the hydrolysis of acetylcholine. ${ }^{10}$ Besides the more traditional therapeutic applications, such as the treatment of myasthenia gravis and glaucoma, AChE inhibitors have recently found a widespread clinical use in the symptomatic treatment of Alzheimer's disease (AD), a progressive degenerative disorder characterized by reduced cholinergic transmission, formation of amyloid plaques and tangles and neuronal loss. ${ }^{11}$, ${ }^{12}$ However, most of the AChE inhibitors on the market suffer from severe side effects and therefore new compounds endowed with improved potency and reduced non-desirable effects are currently pursued.

Recently, our group has published the synthesis and the biological activity of a series of 7substitued coumarin derivatives of general structure $\mathbf{I}$ displaying a dual AChE/MAO inhibitory activity (Figure 1). ${ }^{13}$ The inhibitory potency towards the MAO, in particular the MAO-B isoform, was in the nanomolar range, whereas a lower potency, in the micromolar range, was found against AChE. The absence of protonated or quaternary nitrogen atoms in compounds $\mathbf{I}$ and the prevalent hydrophobic character of the substituted coumarin moieties, suggested that the inhibitory activity of $\mathbf{I}$ could arise from an interaction at the peripheral binding site located at the entrance of the enzymic gorge ending with the primary (anionic) binding site. Molecular docking studies (data not shown) confirmed the correctness of this hypothesis.

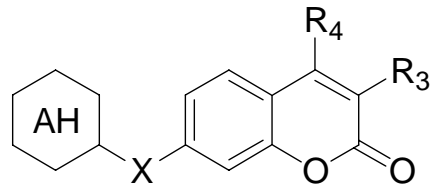

Figure 1. General structure of AChE/MAO dual inhibitors. $\mathrm{X}=$ one- or two-atom bridge; $\mathrm{AH}=$ aromatic or heteroaromatic moiety. 
Aiming at the recovery of a second strong interaction at the primary binding site, able to significantly enhance the low AChE inhibitory potency observed in compounds $\mathbf{I}$, we designed and prepared a small library of potential dual binding site inhibitors, represented by the general structures $\mathbf{A}$ and $\mathbf{B}$ in Figure 2.<smiles>[R]N(C)c1cc(O)cc(OCC(C)Oc2ccc3c(C)c(C)c(=O)oc3c2)c1</smiles>

A<smiles></smiles>

B

$$
\begin{aligned}
& \mathrm{n}=3,4 \\
& \mathrm{R}=\mathrm{CH}_{3}, \mathrm{Bn}
\end{aligned}
$$

Figure 2. General structures of targeted molecules.

\section{Results and Discussion}

Wang resin ${ }^{14}$ was selected as the most appropriate solid support to efficiently load the starting building block, that is the 3,5-dihydroxy-dimethylaniline $\mathbf{1}^{15}$, and to easily cleave the final compounds from the resin in mild conditions. Unfortunately, the direct loading of 1 onto the brominated Wang resin 10 ( prepared according to path a) in Scheme 1) using the sterically hindered strong base KHMDS [potassium bis(trimethylsilyl)amide] to ensure the complete deprotonation of one phenolic group, gave, after cleavage, a mixture of different products (path b) Scheme 1).

a)

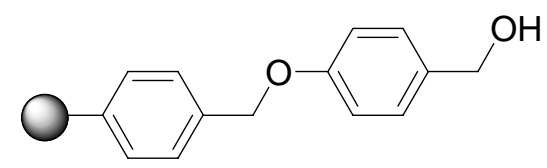

Wang resin

b)

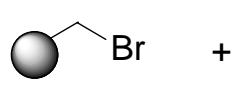

10<smiles>CN(C)c1cc(O)cc(O)c1</smiles>

1
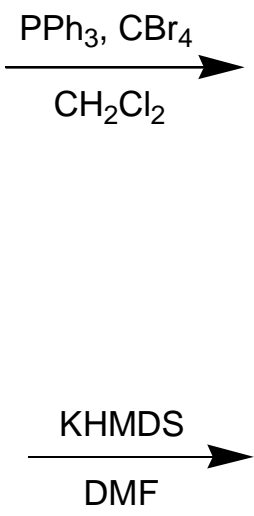<smiles>CN(C)c1cc(O)cc(O)c1CO</smiles>

2

\section{Scheme 1}


As verified in a similar reaction carried out in solution, the synthetic protocol b) depicted in Scheme 1 afforded both $O$ - and $C$-alkylated (on the aromatic ring) products, the latter compound being formed in higher concentration. Thus, to overcome this problem, we decided to protect one of the two hydroxyl groups of $\mathbf{1}$ as a benzoate (3). Indeed, compound 3, obtained by reacting 1 with benzoyl choride in $2 \mathrm{~N} \mathrm{NaOH}$ at $0{ }^{\circ} \mathrm{C}$, was easily loaded in high yield and purity onto the resin 10 using KHMDS as a base and DMF as a solvent (Scheme 2). The resin loading level was evaluated by ${ }^{1} \mathrm{H}-\mathrm{NMR}$ and GC-MS, using 2,6-dimethoxytoluene and 3-dimethylaminophenol respectively as internal standards. Further attempts aimed at improving the efficiency of this step, allowed us to determine the best experimental conditions: 3 fold excess of both compound 3 and KHMDS, in DMSO, instead of DMF as solvent. No significant effect on the reaction yield was observed upon temperature changes.

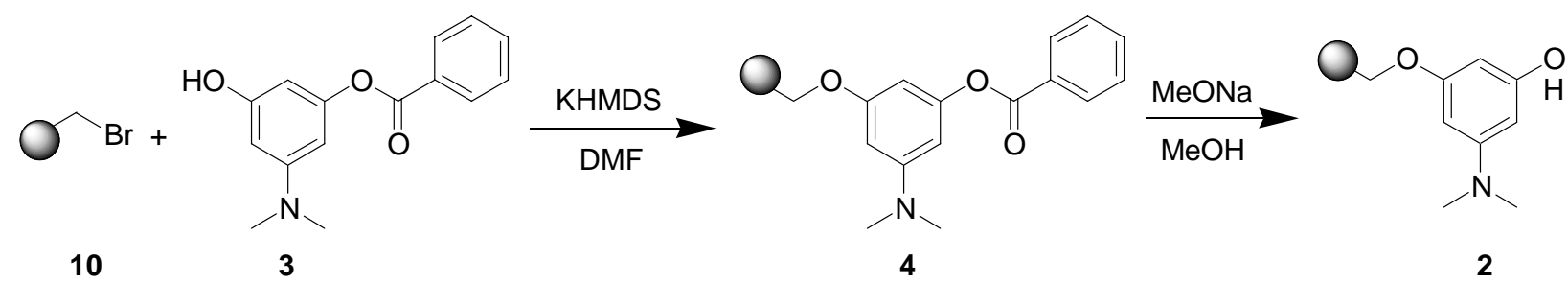

Scheme 2

The second step in our synthetic scheme was the introduction of a suitable aliphatic spacer, as represented in Figure 2. Under the same experimental conditions of the first step, the alkylation reaction afforded two principal products, identified again as the $O$ - and $C$-alkylated derivatives. Despite the wide range of reaction conditions explored, such as the use of different bases (DBU and $\mathrm{NaH}$ ), solvents (DMF and DMSO), electrophiles (alkyl chlorides and bromides) and temperatures, the yields of the reactions were always unsatisfactorily low. Finally, we decided to apply the Mitsunobu reaction ${ }^{16}$ to overcome the previous drawbacks. As auspicated, by using $\mathrm{PPh}_{3}$ (triphenylphosphine), DIAD (diisopropyl azodicarboxylate), and 1,3-propan- or 1,4-butan-diol in THF, the reaction allowed selective alkylation of the phenolic oxygen (Scheme 3). Starting from this encouraging result we tried to improve the efficiency of the reaction by testing different reagents and experimental conditions. The use of a 6 fold excess of ADDP [1,1'(azodicarbonyl)dipiperidine] and $\mathrm{PBu}_{3}$ (tributylphosphine) in $\mathrm{CH}_{2} \mathrm{Cl}_{2}$ gave the best results in terms of reaction yields and compound purity.<smiles>CN(C)c1cc(O)cc(OCc2ccccc2)c1</smiles>

\section{Scheme 3}


The last step of our synthetic pathway was the introduction of an aromatic moiety, such as $\mathbf{1}$ or 3,4-dimethyl-7-hydroxycoumarin 7. ${ }^{17}$ The good results given by the Mitsunobu reaction in the previous step, prompted us to extend the same protocol also to this step (Scheme 4).<smiles>CC(O)COc1cc(OCc2ccccc2)cc(N(C)C)c1</smiles>

Scheme 4

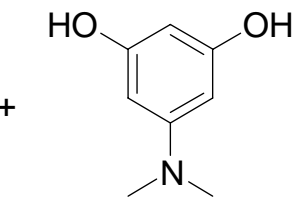

1
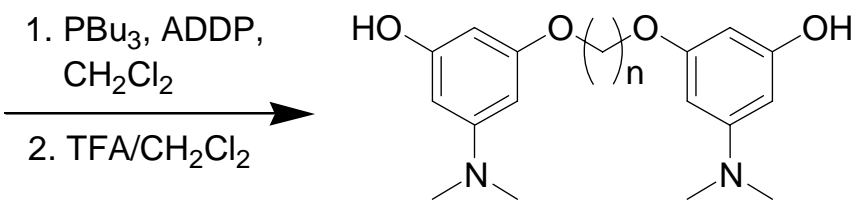

After exploring a wide range of reaction conditions, we realized that those found in the second step gave the best results. The subsequent deprotection and cleavage reactions furnished the desired compound in good yield and purity as assessed by ESI-MS and ${ }^{1} \mathrm{H}-\mathrm{NMR}$ analyses. However, we targeted two chemical steps that could be improved to ameliorate the efficiency, yield and compound purity of our protocol, that are the protection of $\mathbf{1}$ and the coupling of the alkyl spacer. We decided therefore to use a different protecting group for $\mathbf{1}$, to monoprotect the alkyldiol in order to reduce possible side reactions and the amount of ADDP and $\mathrm{PBu}_{3}$ needed to drive the reaction to completion. The TIPS (triisopropylsilyl) protecting group was selected because its introduction and subsequent removal are high yielding and chemoselective. To protect one hydroxyl group of the alkane diols we selected the silylated reagent TBDMSCl ( t.butyldimethylsilyl chloride). Unfortunately, the subsequent loading of compound 5 onto the resin 10, carried out following the experimental conditions assessed previously, gave no improvement of the yield, since the reaction led to a number of undesired compounds as determined by GC-MS. Finally we successfully applied the Mitsunobu protocol also to load 5 onto the resin. The best results in terms of yield and purity were obtained using a 3 fold excess of $5, \mathrm{PPh}_{3}$ and DIAD in THF at room temperature.

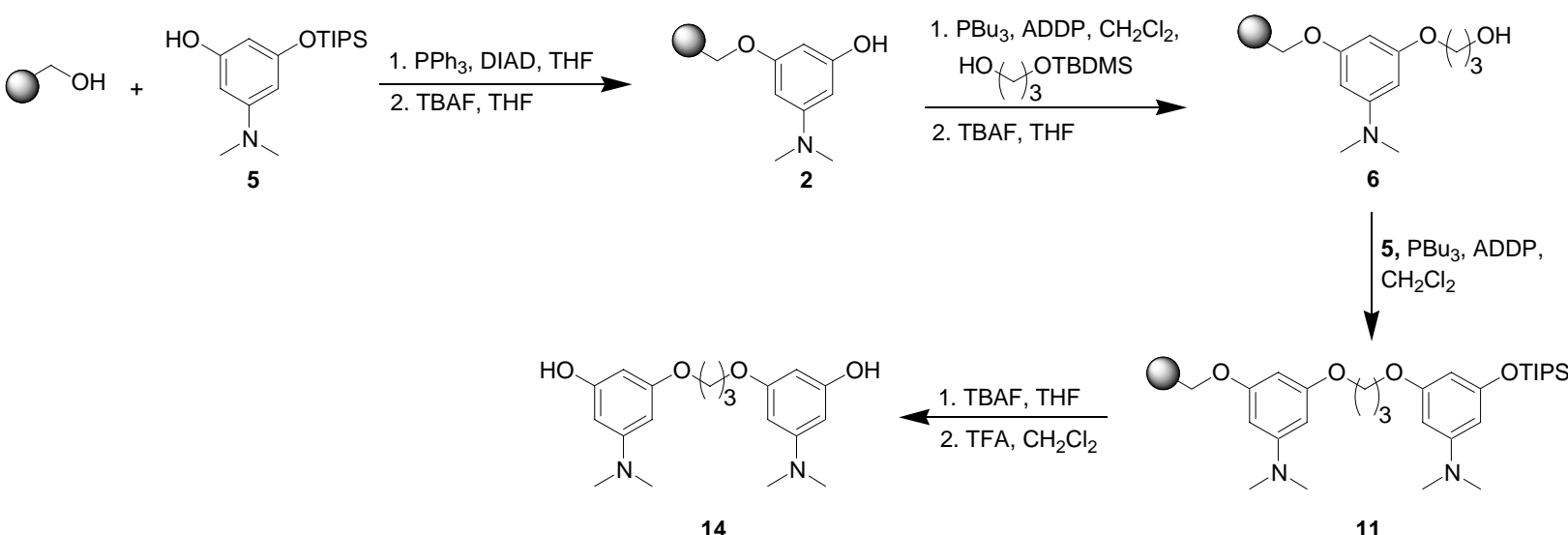

Scheme 5 
The deprotection of the phenolic and alcoholic hydroxyls, made with TBAF ( tetrabutylammonium fluoride), afforded the expected compounds in quantitative yields The definitive overall synthetic pathway, outlined in Scheme 5, was validated with the preparation of compound $\mathbf{1 4}$ which was obtained in good yield and purity as assessed by TLC, ESI-MS and ${ }^{1} \mathrm{H}-$ NMR analyses. The overall yield determined by ${ }^{1} \mathrm{H}-\mathrm{NMR}$ analysis, using 2,6-dimethoxytoluene as internal standard, was $50 \%$ as a result of 7 consecutive steps with a purity greater than $80 \%$.

The synthetic pathway described above was applied to the preparation of a small library of potential AChE inhibitors (Scheme 6), that was carried out in parallel using the organic synthesizer Quest 210. The quaternization of compounds 20-23 was made in solution after cleavage of the tertiary amines from the resin, using a 20 fold excess of $\mathrm{CH}_{3} \mathrm{I}$ in $\mathrm{CH}_{3} \mathrm{CN}$. The ESI-MS and the ${ }^{1} \mathrm{H}-\mathrm{NMR}$ data of compounds 14-27 highlight the efficacy of the reported method. The yields and the purity of all compounds were comparable with those determined above for derivative 14 .
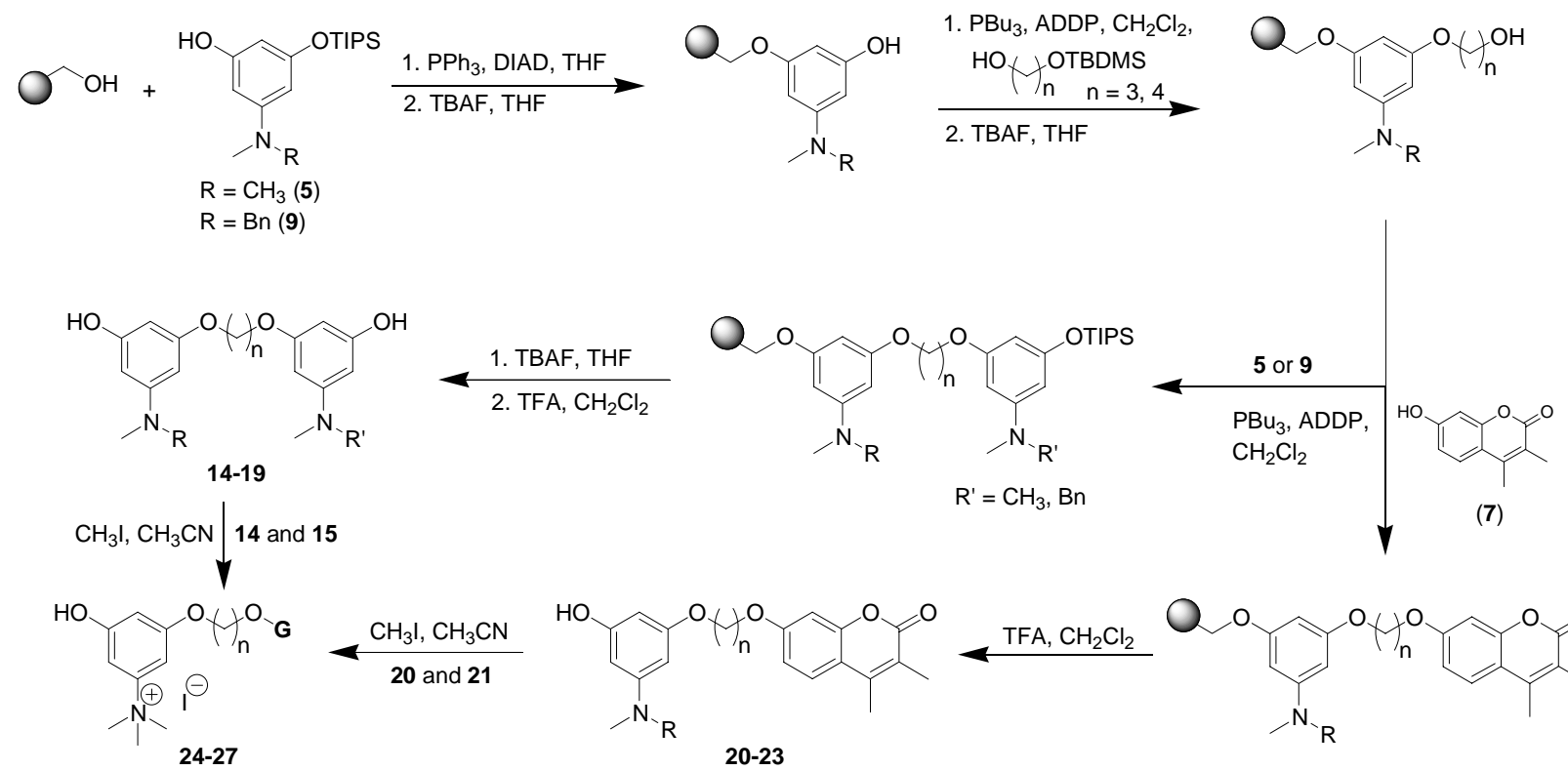

\begin{tabular}{cccccccccccccccc}
\hline & $\mathbf{1 4}$ & $\mathbf{1 5}$ & $\mathbf{1 6}$ & $\mathbf{1 7}$ & $\mathbf{1 8}$ & $\mathbf{1 9}$ & $\mathbf{2 0}$ & $\mathbf{2 1}$ & $\mathbf{2 2}$ & $\mathbf{2 3}$ & & $\mathbf{2 4}$ & $\mathbf{2 5}$ & $\mathbf{2 6}$ & $\mathbf{2 7}$ \\
\hline $\mathbf{n}$ & 3 & 4 & 3 & 4 & 3 & 4 & 3 & 4 & 3 & 4 & $\mathbf{n}$ & 3 & 4 & 3 & 4 \\
$\mathbf{R}$ & $\mathrm{Me}$ & $\mathrm{Me}$ & $\mathrm{Bn}$ & $\mathrm{Bn}$ & $\mathrm{Bn}$ & $\mathrm{Bn}$ & $\mathrm{Me}$ & $\mathrm{Me}$ & $\mathrm{Bn}$ & $\mathrm{Bn}$ & & & \\
$\mathbf{R}$ & $\mathrm{Me}$ & $\mathrm{Me}$ & $\mathrm{Me}$ & $\mathrm{Me}$ & $\mathrm{Bn}$ & $\mathrm{Bn}$ & - & - & - & - & & & & &
\end{tabular}

\section{Scheme 6}

Although the solid phase synthesis enables a rapid preparation of libraries of compounds, the work needed to assess the best reaction conditions is often tedious and time consuming. Indeed, the optimization of the synthetic protocol for the preparation of the compounds depicted in Figure 2 required a full exploitation of different chemical strategies. Among the wide variety of 
the chemical reactions and experimental conditions explored, the Mitsunobu protocol offered the best results in terms of purity and yields, as verified by ESI-MS (Figure 3) and ${ }^{1} \mathrm{H}-\mathrm{NMR}$ analyses.

a)

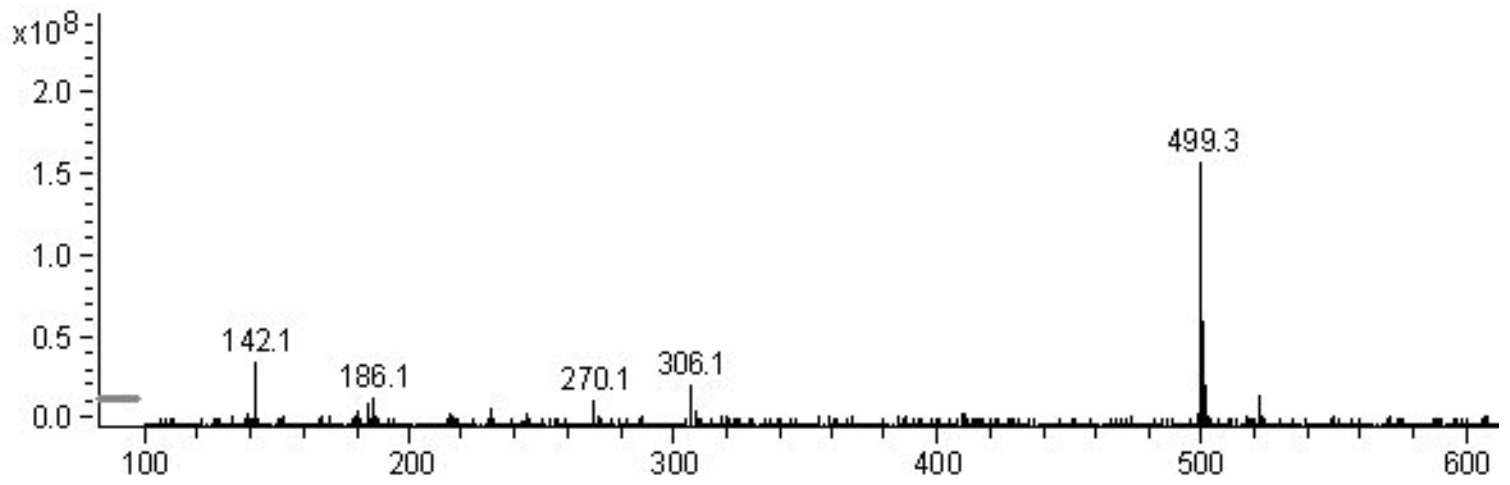

b)

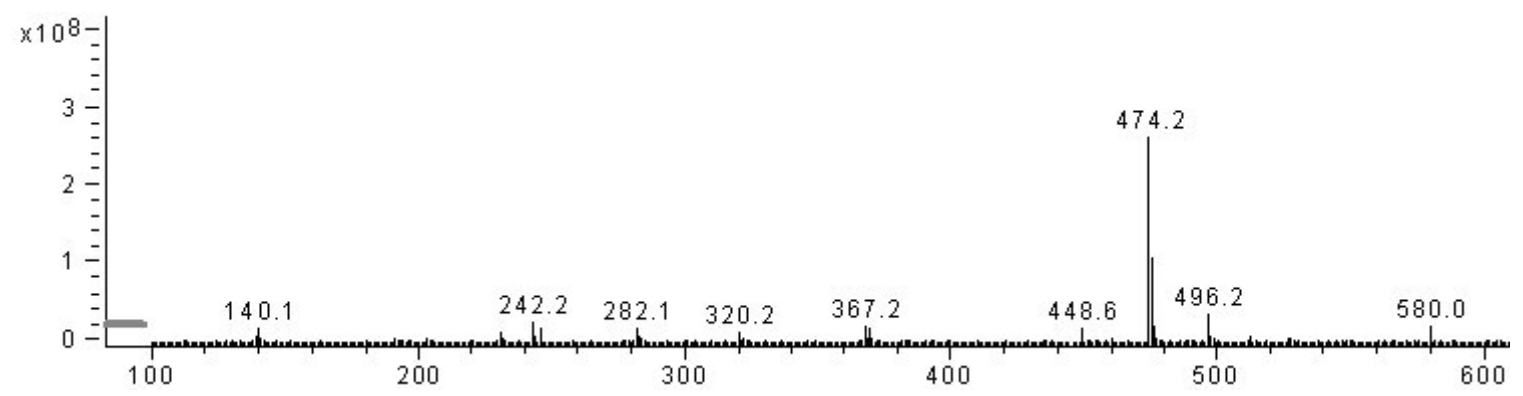

Figure 3. Representative examples of ESI-MS: a) 18: $499.3[\mathrm{M}+\mathrm{H}]^{+}$; b) 23: $474.2[\mathrm{M}+\mathrm{H}]^{+}$, $496.2[\mathrm{M}+\mathrm{Na}]^{+}$

In this regard, it must be underlined that even if the synthesis of the library was carried out through a sequence of the same type of reactions, the experimental conditions adopted in each step, i.e. stoichometry, reagents and solvents, were different depending on the reactivity of the species involved in the reaction. In fact, in the first step, the loading of compound $\mathbf{5}$ was performed in THF using DIAD and $\mathrm{PPh}_{3}$ as the coupling reagents. As outlined by the ${ }^{1} \mathrm{H}-\mathrm{NMR}$ spectra and GC-MS analyses of the products obtained from the resin cleavage, those experimental conditions guaranteed the complete transformation of the starting material and the formation of the desired product in good yield and purity. The optimization of the next two steps was more time consuming, because of the low reactivity of the diol. In fact, differently from the first step, the SN type reactions were not suited for the coupling of $\mathbf{2}$ with a dibromoalkane, because the reaction gave, again the two $O$ - and $C$-alkylated products. Moreover, using the cheaper and safer Mitsunobu protocol adopted in the first step, the yield of the reaction was low, because of the reduced reactivity of the diol. In fact, to ensure a complete transformation of the starting material we had to use different reagents such as ADDP and $\mathrm{PBu}_{3}$, that favored the 
formation of a more reactive intermediate. Furthermore, the $\mathrm{CH}_{2} \mathrm{Cl}_{2}$ solvent gave better results compared to THF and diverse $\mathrm{THF} / \mathrm{CH}_{2} \mathrm{Cl}_{2}$ mixtures.

\section{Conclusions}

The synthetic method proposed in this report allowed the facile and straightforward preparation of a small library of bioactive compounds in a parallel fashion. The protocol may be applied to the preparation of larger libraries containing a variety of structural modifications in the spacer, in the N-alkyl groups and in the phenolic moieties. Properly designed structural variations should allow to explore and map, in full details, the key binding regions at both anionic and peripheral binding sites of both the $\mathrm{AChE}$ and $\mathrm{BChE}$ targeted enzymes. More particularly, a fully exploration of the possible interactions at the AChE peripheral binding sites should be pursued and preferred, since, as highlighted in a recently published paper, ${ }^{18} \mathrm{AChE}$ inhibitors that interact at those binding sites could diminish the $\beta$-amyloid aggregation and this surely constitutes an additional pharmacological action, highly desirable for the treatment of Alzheimer's disease.

The compounds described in this work will be therefore tested as $\mathrm{AChE}$ and $\mathrm{BChE}$ inhibitors, both as free amines and as methylammonium quaternary salts. The results from the ongoing studies of enzyme inhibition, SAFIR and molecular docking will be reported in due course.

\section{Experimental Section}

General Procedures. Wang resin-100-200 mesh, loading level $0.83 \mathrm{mmol} / \mathrm{g}$ - was purchased from Novabiochem. Unless otherwise stated, reagents and solvents were obtained from commercial sources and used without further purification. Column chromatography was carried out using Merck 60 (0.063-0.200 mm) silica gel. Flash chromatography was performed on Merck $60(0.015-0.040 \mathrm{~mm})$ silica gel, according to the procedure of Still. ${ }^{19}$ Thin-layer chromatography was carried out on Merck 60 F254 250- $\mu$ m silica gel plates. Reagent grade THF was distilled under $\mathrm{N}_{2}$ from sodium/benzophenone ketyl, whereas $\mathrm{CH}_{2} \mathrm{Cl}_{2}$ was distilled on calcium hydride under $\mathrm{N}_{2}$. Melting points were determined by the capillary method on a Stuart Scientific SMP-3 apparatus and are uncorrected. IR spectra were recorded as $\mathrm{KBr}$ pellets on a Perkin Elmer FT-IR spectrophotometer. Unless otherwise indicated ${ }^{1} \mathrm{H}-\mathrm{NMR}$ spectra were recorded in Acetone- $\mathrm{d}_{6}$ at $300 \mathrm{MHz}$ on a Brucker 300 instrument. Chemical shifts are reported in $\delta$ (ppm) downfield from an internal solvent peak and $J$ values are in hertz. The ${ }^{1} \mathrm{H}-\mathrm{NMR}$ for the test compound 14 was recorded in DMSO-d $\mathrm{d}_{6}$, using 2,6-dimethoxytoluene as internal standard [ $\delta: 1.95(\mathrm{~s}, 3 \mathrm{H}), 3.72(\mathrm{~s}$, $6 \mathrm{H}), 6.57(\mathrm{~d}, 2 \mathrm{H}, \mathrm{J}=8.32), 7.08(\mathrm{t}, 1 \mathrm{H}, \mathrm{J}=8.35)$ ]. ESI-MS data were acquired on a Agilent 1100 series LC/MSD Trap. Standard electrospray operating conditions were as follows: spray voltage $5.5 \mathrm{kV}$, capillary temperature $275^{\circ} \mathrm{C}$, capillary voltage $20 \mathrm{~V}$, tube lens offset voltage $40 \mathrm{~V}$. The 
sample solutions were infused via a Harvard syringe pump at a constant flow rate. Data were acquired in the positive MS/MS product ion mode.

3-(Dimethylamino)-5-hydroxyphenylbenzoate (3). $2.7 \mathrm{~g}$ (17.6 mmol) of 5-dimethylamino-1,3benzenediol (1) were solubilized in a $2 \mathrm{~N}$ solution of $\mathrm{NaOH}(17.6 \mathrm{~mL})$. To this solution was added, at $0{ }^{\circ} \mathrm{C}$ under magnetic stirring, benzoylchloride $(0.68 \mathrm{~mL}, 5.9 \mathrm{mmol})$ diluted in $1 \mathrm{~mL}$ of DMF. After $20 \mathrm{~min}$. the mixture was extracted with AcOEt. The organic layer was separated, dried over $\mathrm{Na}_{2} \mathrm{SO}_{4}$, concentrated under vacuum and purified by flash chromatography to give $0.5 \mathrm{~g}(50 \%)$ of 3 as a dark orange oil. ${ }^{1} \mathrm{H}-\mathrm{NMR} \delta: 2.92(\mathrm{~s}, 6 \mathrm{H}), 6.11(\mathrm{t}, 1 \mathrm{H}, \mathrm{J}=2.0), 6.13-6.16$ $(\mathrm{m}, 2 \mathrm{H}), 7.59$ (t, 2H, J= 7.3), $7.71(\mathrm{tt}, 1 \mathrm{H}, \mathrm{J}=7.3,1.6), 8.13-8.17(\mathrm{~m}, 2 \mathrm{H}), 8.27(\mathrm{~s}, 1 \mathrm{H})$.

3-(Dimethylamino)-5-(triisopropylsilanyloxy)phenol (5). To a solution of 1 (8.4 g, $55 \mathrm{mmol})$ in anhydrous $\mathrm{CH}_{2} \mathrm{Cl}_{2}(210 \mathrm{~mL})$, were added imidazole $(9.4 \mathrm{~g}, 137.5 \mathrm{mmol})$, 4dimethylaminopyridine (DMAP) (3.4 g, $27.5 \mathrm{mmol})$ and triisopropilsilyl chloride (TIPSCl) $(12.9 \mathrm{~mL}, 60.5 \mathrm{mmol})$. The mixture was stirred at room temperature for 2 hours, washed with $\mathrm{H}_{2} \mathrm{O}$, dried over $\mathrm{Na}_{2} \mathrm{SO}_{4}$ then purified by column chromatography, using, as the eluents, $\mathrm{CHCl}_{3} /$ hexane 8:2, then $\mathrm{CHCl}_{3}$ up to the elution of the first spot and finally $\mathrm{CHCl}_{3} / \mathrm{AcOEt}$ 8:2. The eluate corresponding to the desired product was concentrated under vacuum to give $4.9 \mathrm{~g}$ $(65 \%)$, of a pure pink oil that solidifies on standing, mp $67-68^{\circ} \mathrm{C} .{ }^{1} \mathrm{H}-\mathrm{NMR}\left(\mathrm{CDCl}_{3}\right) \delta 1.10(\mathrm{~d}$, $18 \mathrm{H}, \mathrm{J}=6.6), 1.16-1.33(\mathrm{~m}, 3 \mathrm{H}), 2.88(\mathrm{~s}, 6 \mathrm{H}), 4.75(\mathrm{~b}, 1 \mathrm{H}), 5.80(\mathrm{t}, 1 \mathrm{H}, \mathrm{J}=2.1), 5.83(\mathrm{t}, 1 \mathrm{H}, \mathrm{J}$ $=2.1), 5.88(\mathrm{t}, 1 \mathrm{H}, \mathrm{J}=2.1) . \mathrm{IR}\left(\mathrm{cm}^{-1}\right) 3293,2944,2867,1616,1587,1150,1029,884$.

5-( $N$-Benzyl- $N$-methylamino)-benzene-1,3-diol (8). To a solution of 1,3,5-trihydroxybenzene (7.8 g, $61.7 \mathrm{mmol})$ in DMF $(108 \mathrm{~mL})$ and $\mathrm{H}_{2} \mathrm{O}(46 \mathrm{~mL})$ was added under argon $\mathrm{N}$ benzylmethylamine $(10.1 \mathrm{~mL}, 78.5 \mathrm{mmol})$, then heated to $50{ }^{\circ} \mathrm{C}$. After 24 hours the mixture was concentrated under vacuum to obtain a dark oil, that was purified by column chromatography using $\mathrm{CHCl}_{3} / \mathrm{AcOEt} /$ petroleum ether 4:4:2, as eluent, to give $7.2 \mathrm{~g}(60 \%)$ of an oil of sufficient analytical purity. ${ }^{1} \mathrm{H}-\mathrm{NMR}\left(\mathrm{DMSO}_{-} \mathrm{d}_{6}\right) \delta 2.89(\mathrm{~s}, 3 \mathrm{H}), 4.41(\mathrm{~s}, 2 \mathrm{H}), 5.54-5.58(\mathrm{~m}, 3 \mathrm{H}), 7.14-7.21$ (m, 3H), 7.26-7.31 (m, 2H), 8.79 (s, 2H).

3-( $N$-Benzyl- $N$-methylamino)-5-(triisopropylsilanyloxy)phenol (9). To a solution of 8 (6.9 g, $30 \mathrm{mmol})$, in anhydrous $\mathrm{CH}_{2} \mathrm{Cl}_{2}(114 \mathrm{~mL})$, were added imidazole (5.1 g, $\left.75 \mathrm{mmol}\right)$, DMAP $(1.8 \mathrm{~g}, 15 \mathrm{mmol})$ and TIPSCl $(7.1 \mathrm{~mL}, 33 \mathrm{mmol})$. The reaction mixture was stirred for 2 hours at room temperature, then washed with $\mathrm{H}_{2} \mathrm{O}$. The organic layer was dried over $\mathrm{Na}_{2} \mathrm{SO}_{4}$, concentrated and purified by column chromatography, using, as the eluents, $\mathrm{CHCl}_{3} / \mathrm{exane} 8: 2$, then $\mathrm{CHCl}_{3}$ up to the elution of the first spot and finally $\mathrm{CHCl}_{3} / \mathrm{AcOEt} 8: 2$ to furnish $3.8 \mathrm{~g}(50 \%)$ of a red oil. ${ }^{1} \mathrm{H}-\mathrm{NMR}\left(\mathrm{CDCl}_{3}\right) \delta 1.04(\mathrm{~d}, 18 \mathrm{H}, \mathrm{J}=6.0), 1.08-1.16(\mathrm{~m}, 3 \mathrm{H}), 2.99(\mathrm{~s}, 3 \mathrm{H}), 4.47(\mathrm{~s}$, $2 \mathrm{H}), 4.57(\mathrm{~s}, 1 \mathrm{H}), 5.78(\mathrm{t}, 1 \mathrm{H}, \mathrm{J}=1.9), 5.84(\mathrm{t}, 2 \mathrm{H}, \mathrm{J}=1.9), 7.17-7.32(\mathrm{~m}, 5 \mathrm{H}) . \mathrm{IR}\left(\mathrm{cm}^{-1}\right) 3375$, 2944, 2866, 1615, 1584, 1505, 1152, 1024, 883, 821.

Brominated Wang resin (10). The Wang resin $(1.0 \mathrm{~g}, 0.8 \mathrm{mmol}))$ was swelled in anhydrous $\mathrm{CH}_{2} \mathrm{Cl}_{2}(15 \mathrm{~mL})$ for $30 \mathrm{~min}$. then filtered. To the resin was added anhydrous $\mathrm{CH}_{2} \mathrm{Cl}_{2}(5 \mathrm{~mL})$ and $\mathrm{CBr}_{4}(0.6 \mathrm{~g}, 1.9 \mathrm{mmol})$, followed by cooling to $0{ }^{\circ} \mathrm{C}$. A solution of $\mathrm{PPh}_{3}(0.45 \mathrm{~g}, 1.7 \mathrm{mmol})$ in $\mathrm{CH}_{2} \mathrm{Cl}_{2}(3 \mathrm{~mL})$ was slowly added and the mixture was gently stirred for $5 \mathrm{~min}$, before allowing 
the temperature to rise up to room temperature. The reaction mixture was gently stirred at room temperature for 4 hours, the resin filtered off, washed with $\mathrm{CH}_{2} \mathrm{Cl}_{2}(3 \times 15 \mathrm{~mL})$, dried under vacuum and employed in the coupling step within 48 hours of preparation.

3-(tert-Butyl-dimethyl-silanyloxy)propan-1-ol (12), 4-(tert-butyl-dimethyl-silanyloxy)butan-1-ol (13). To a suspension of $\mathrm{NaH}(0.52 \mathrm{~g}, 13.1 \mathrm{mmol})$ in THF $(26 \mathrm{~mL})$ was added 1,3propandiol or 1,4-butandiol (13.1 mmol, $0.9 \mathrm{~mL}$ and $1.16 \mathrm{~mL}$ respectively), followed after 45 min by $t$-butyldimethylsilyl chloride (TBDMSCl) $(2.0 \mathrm{~g}, 13.3 \mathrm{mmol})$. The mixture was stirred at room temperature for $45 \mathrm{~min}$, thus diluted with $\mathrm{Et}_{2} \mathrm{O}(200 \mathrm{~mL})$. The organic layer was extracted with a $10 \%$ solution of $\mathrm{K}_{2} \mathrm{CO}_{3}$, washed with brine, dried over $\mathrm{Na}_{2} \mathrm{SO}_{4}$, then concentrated under vacuum to give a yellow oil, that was purified by flash chromatography using hexane/AcOEt 8:2 as eluent.

Compound 12. Yield: 77\%. ${ }^{1} \mathrm{H}-\mathrm{NMR}\left(\mathrm{CDCl}_{3}\right) \delta 0.07(\mathrm{~s}, 6 \mathrm{H}), 0.90(\mathrm{~s}, 9 \mathrm{H}), 1.78(\mathrm{qn}, 2 \mathrm{H}, \mathrm{J}=5.5)$, 2.59 (b, 1H), 3.78-3.85 (m, 4H). IR ( $\left.\mathrm{cm}^{-1}\right)$ 3357, 2949, 2930, 2858, 1256, 1098, 837.

Compound 13. Yield: 82\%. ${ }^{1} \mathrm{H}-\mathrm{NMR}\left(\mathrm{CDCl}_{3}\right) \delta 0.06(\mathrm{~s}, 6 \mathrm{H}), 0.89(\mathrm{~s}, 9 \mathrm{H}), 1.60-1.68(\mathrm{~m}, 4 \mathrm{H})$, 2.59 (b, 1H), 3.62-3.68 (m, 4H). IR ( $\left.\mathrm{cm}^{-1}\right)$ 3357, 2942, 2931, 2859, 1256, 1101, 837.

Coupling of 3 to the brominated Wang resin (10). To a round bottom flask, flame dried, were added under argon $3(0.12 \mathrm{~g}, 0.47 \mathrm{mmol})$, anhydrous DMSO $(2 \mathrm{~mL})$ and a $0.5 \mathrm{M}$ solution of KHMDS in toluene $(0.95 \mathrm{~mL}, 0.47 \mathrm{mmol})$. The mixture was stirred for $5 \mathrm{~min}$ then added to the brominated Wang resin $10(0.2 \mathrm{~g}, 0.16 \mathrm{mmol})$, previously swelled in DMSO (4 mL). After 4 hours, the resin was filtered and washed with DMSO (3 x $4 \mathrm{~mL})$, THF (3 x $4 \mathrm{~mL})$ and $\mathrm{MeOH}(3$ $\mathrm{x} 4 \mathrm{~mL}$ ) and then dried under vacuum. The resin was recovered, swelled in anhydrous THF (4 $\mathrm{mL})$, filtered, suspended in THF (2 mL) and treated with a saturated solution of MeONa in anh. $\mathrm{MeOH}(0.12 \mathrm{~mL})$. The reaction mixture was stirred for 4 hours, filtered and washed with THF/ $\mathrm{H}_{2} \mathrm{O}$ 1:1 (3 x $\left.\left.4 \mathrm{~mL}\right), \mathrm{THF} / 2 \mathrm{~N} \mathrm{HCl} \mathrm{1:1} \mathrm{(3} \mathrm{x} 4 \mathrm{~mL}\right), \mathrm{THF} / \mathrm{H}_{2} \mathrm{O}$ 1:1 (3 x $\left.4 \mathrm{~mL}\right), \mathrm{THF}(3 \mathrm{x}$ $4 \mathrm{~mL}), \mathrm{MeOH}(3 \times 4 \mathrm{~mL})$, ethyl ether $(3 \times 4 \mathrm{~mL})$.

\section{Synthesis of the library reported in Scheme 6 (cps 14-23)}

$2.0 \mathrm{~g}(1.7 \mathrm{mmol})$ of Wang resin were equally divided in ten reaction tubes of the Quest 210 apparatus and swelled with anhydrous THF (4 mL per tube) for $30 \mathrm{~min}$. In two separated, flame dried, round bottom flasks were placed $2.5 \mathrm{mmol}$ of $5(0.64 \mathrm{~g})$ or $9(0.96 \mathrm{~g})$. To each round bottom flask were added under argon THF $(20 \mathrm{~mL})$ and DIAD $(0.49 \mathrm{~mL}, 2.5 \mathrm{mmol})$. These two solutions, divided in 5 aliquots, were added to the resin ( 1 aliquot per tube). To each tube was added $\mathrm{PPh}_{3}(0.13 \mathrm{~g}, 0.5 \mathrm{mmol})$ and the mixture was stirred for 18 hours under nitrogen. The resins were filtered and washed with THF (3 x $4 \mathrm{~mL})$, DMF $(3 \times 4 \mathrm{~mL})$, THF $(3 \times 4 \mathrm{~mL})$. To the resins were added THF $(1 \mathrm{~mL})$ and a $1 \mathrm{M}$ solution of TBAF in THF $(1 \mathrm{~mL})$ and allowed to react for 1 hour. The solvent was filtered and the resin washed with THF ( $3 \times 2 \mathrm{~mL}), \mathrm{THF} / \mathrm{H}_{2} \mathrm{O}$ 1:1 (3 x $2 \mathrm{~mL}), \mathrm{THF}(3 \times 2 \mathrm{~mL}), \mathrm{CH}_{2} \mathrm{Cl}_{2}(3 \times 2 \mathrm{~mL}), \mathrm{MeOH}(3 \times 2 \mathrm{~mL})$ and finally dried under vacuum over $\mathrm{P}_{2} \mathrm{O}_{5}$. The resins were swelled in $\mathrm{CH}_{2} \mathrm{Cl}_{2}$ for $30 \mathrm{~min}$, filtered and treated with the TBDSprotected diols 12 and 13 (0.51 mmol, $97 \mathrm{mg}$ and $104 \mathrm{mg}$ respectively), using $\mathrm{CH}_{2} \mathrm{Cl}_{2}(2 \mathrm{~mL})$. To 
each tube were added ADDP $(0.13 \mathrm{~g}, 0.51 \mathrm{mmol}), \mathrm{PBu}_{3}(0.13 \mathrm{~mL}, 0.51 \mathrm{mmol})$ and the mixtures were stirred for 18 hours. After filtering and washing with $\mathrm{CH}_{2} \mathrm{Cl}_{2}(3 \times 2 \mathrm{ml}) \mathrm{THF}(3 \times 2 \mathrm{~mL})$, DMF $(3 \times 2 \mathrm{~mL})$, THF $(3 \times 2 \mathrm{~mL}), \mathrm{CH}_{2} \mathrm{Cl}_{2}(3 \times 2 \mathrm{~mL})$, the coupling was repeated twice in the same conditions. At this point, the resin, filtered and washed as above, was suspended in THF $(1 \mathrm{~mL})$ and treated with TBAF $(1 \mathrm{~mL})$ for 1 hour, thus filtered and washed with THF $(3 \times 2 \mathrm{~mL})$, $\mathrm{THF} / \mathrm{H}_{2} \mathrm{O}$ 1:1 (3 x $\left.2 \mathrm{~mL}\right)$, THF (3 x $\left.2 \mathrm{~mL}\right), \mathrm{CH}_{2} \mathrm{Cl}_{2}(3 \times 2 \mathrm{~mL}), \mathrm{MeOH}(3 \times 2 \mathrm{~mL})$ and finally dried under vacuum over $\mathrm{P}_{2} \mathrm{O}_{5}$. The resin was swelled in $\mathrm{CH}_{2} \mathrm{Cl}_{2}$ for $30 \mathrm{~min}$ before the final coupling with 5,9 or 7 . Thus, to the selected tubes were added $5(0.16 \mathrm{~g}, 0.51 \mathrm{mmol}), 9(0.2 \mathrm{~g}$, $0.51 \mathrm{mmol})$ and $7(0.97 \mathrm{~g}, 0.51 \mathrm{mmol})$, followed by $\mathrm{CH}_{2} \mathrm{Cl}_{2}(2 \mathrm{~mL})$, ADDP $(0.13 \mathrm{~g}, 0.51 \mathrm{mmol})$, $\mathrm{PBu}_{3}(0.13 \mathrm{~mL}, 0.51 \mathrm{mmol})$. After filtering and washing as described before, the coupling was repeated twice. The resin carrying the TIPS protected compounds was suspended in THF (1 mL) and treated with a $1 \mathrm{M}$ solution of TBAF in THF $(1 \mathrm{~mL})$. The solvent was filtered and the resin

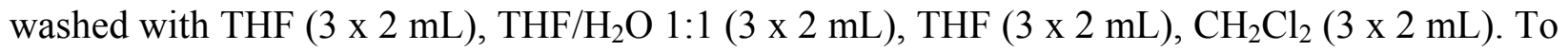
the resin swelled in $\mathrm{CH}_{2} \mathrm{Cl}_{2}$ were added a $50 \%$ solution of TFA in $\mathrm{CH}_{2} \mathrm{Cl}_{2}(2 \mathrm{~mL})$. After 1 hour stirring under nitrogen, the resin was filtered and washed with the same mixture of cleavage $(3 \mathrm{x}$ $2 \mathrm{~mL})$. Each solution was evaporated to dryness and to the residue was added toluene $(2 \mathrm{~mL})$ that was in turn removed under vacuum. The last step was repeated 3 times. The oil obtained were washed with $\mathrm{CH}_{2} \mathrm{Cl}_{2}$ and ether to obtain the desired compounds in a sufficiently pure form either in a solid or in an oily form.

3-(Dimethylamino)-5-\{3-[3-(dimethylamino)-5-hydroxyphenoxy]propoxy\}phenol (14). ${ }^{1} \mathrm{H}-\mathrm{NMR}$ $\delta 2.15(\mathrm{qn}, 2 \mathrm{H}, \mathrm{J}=6.2), 2.86(\mathrm{~s}, 12 \mathrm{H}), 4.08(\mathrm{t}, 4 \mathrm{H}, \mathrm{J}=6.2), 5.87$ (s, 6H), 8.06 (s, 2H). MS (ESI), $\mathrm{m} / \mathrm{z}$ calcd for $\mathrm{C}_{19} \mathrm{H}_{26} \mathrm{~N}_{2} \mathrm{O}_{4}$ : 346.4. Found: $347.2[\mathrm{M}+\mathrm{H}]^{+}$.

3-(Dimethylamino)-5-\{4-[3-(dimethylamino)-5-hydroxyphenoxy]butoxy\}phenol (15). ${ }^{1} \mathrm{H}-\mathrm{NMR}$ $\delta$ 1.87-1.91 (m, 4H), $2.86(\mathrm{~s}, 12 \mathrm{H}), 3.96-4.00(\mathrm{~m}, 4 \mathrm{H}), 5.82-5.84(\mathrm{~m}, 6 \mathrm{H}), 7.95(\mathrm{~b}, 2 \mathrm{H})$. MS (ESI), $m / z$ calcd for $\mathrm{C}_{20} \mathrm{H}_{28} \mathrm{~N}_{2} \mathrm{O}_{4}: 360.4$. Found: $361.2[\mathrm{M}+\mathrm{H}]^{+}$.

3-(N-Benzyl- $N$-methylamino)-5-\{3-[3-(dimethylamino)-5-hydroxyphenoxy]propoxy\}phenol (16). ${ }^{1} \mathrm{H}-\mathrm{NMR} \delta$ 1.84-1.87 (m, 2H), $2.86(\mathrm{~s}, 6 \mathrm{H}), 2.98(\mathrm{~s}, 3 \mathrm{H}), 3.93-3.97(\mathrm{~m}, 4 \mathrm{H}), 4.51(\mathrm{~s}, 2 \mathrm{H})$, 5.81-5.88 (m, 6H), 7.21-7.33 (m, 5H), 7.97 (b, 2H). MS (ESI), m/z calcd for $\mathrm{C}_{25} \mathrm{H}_{30} \mathrm{~N}_{2} \mathrm{O}_{4}: 422.5$. Found: $423.3[\mathrm{M}+\mathrm{H}]^{+}$.

3-(N-Benzyl- $N$-methylamino)-5-\{4-[3-(dimethylamino)-5-hydroxyphenoxy]butoxy\}phenol (17). ${ }^{1} \mathrm{H}-\mathrm{NMR} \delta$ 1.84-1.87 (m, 4H), $2.85(\mathrm{~s}, 6 \mathrm{H}), 2.98(\mathrm{~s}, 3 \mathrm{H}), 3.94(\mathrm{t}, 4 \mathrm{H}, \mathrm{J}=6.0), 4.51(\mathrm{~s}, 2 \mathrm{H})$, 5.81-5.87 (m, 6H), 7.21-7.33 (m, 5H), $7.96(\mathrm{~b}, 2 \mathrm{H})$. MS (ESI), m/z calcd for $\mathrm{C}_{26} \mathrm{H}_{32} \mathrm{~N}_{2} \mathrm{O}_{4}: 436.5$. Found: $437.3[\mathrm{M}+\mathrm{H}]^{+}$.

3-( $N$-Benzyl- $N$-methylamino)-5-(4-\{3-[( $N$-Benzyl- $N$-methylamino)]-5-hydroxyphenoxy\}propoxy) phenol (18). ${ }^{1} \mathrm{H}-\mathrm{NMR} \delta$ 2.07-2.10 (m, 2H), $2.97(\mathrm{~s}, 6 \mathrm{H}), 4.02(\mathrm{t}, 4 \mathrm{H}, \mathrm{J}=6.2), 4.50(\mathrm{~s}, 4 \mathrm{H}), 5.82$ $(\mathrm{t}, 2 \mathrm{H}, \mathrm{J}=1.9), 5.86(\mathrm{~d}, 4 \mathrm{H}, \mathrm{J}=1.9), 7.21-7.32(\mathrm{~m}, 10 \mathrm{H}), 8.02(\mathrm{~s}, 2 \mathrm{H})$. MS (ESI), $\mathrm{m} / \mathrm{z}$ calcd for $\mathrm{C}_{31} \mathrm{H}_{34} \mathrm{~N}_{2} \mathrm{O}_{4}$ : 498.6. Found: $499.3[\mathrm{M}+\mathrm{H}]^{+}$.

3-( $N$-Benzyl- $N$-methylamino)-5-(4-\{3-[( $N$-Benzyl- $N$-methylamino)]-5-hydroxyphenoxy\}butoxy) phenol (19). ${ }^{1} \mathrm{H}-\mathrm{NMR} \delta 1.83-1.84(\mathrm{~m}, 4 \mathrm{H}), 2.98$ (s, 6H), 3.92 (b, 4H), 4.51 (s, 4H), 5.80-5.84 (m, 
2H), 5.85-5.90 (m, 4H), 7.21-7.33 (m, 10H), $7.95(\mathrm{~s}, 2 \mathrm{H})$. MS (ESI), $\mathrm{m} / \mathrm{z}$ calcd for $\mathrm{C}_{32} \mathrm{H}_{36} \mathrm{~N}_{2} \mathrm{O}_{4}$ : 512.6. Found: $513.2[\mathrm{M}+\mathrm{H}]^{+}$.

7-\{[3-(3-Dimethylamino-5-hydroxyphenoxy)propoxy]\}-3,4-dimethyl-2H-chromen-2-one (20). ${ }^{1} \mathrm{H}-\mathrm{NMR} \delta 2.11(\mathrm{~s}, 3 \mathrm{H}), 2.24(\mathrm{qn}, 2 \mathrm{H}, \mathrm{J}=6.0), 2.40(\mathrm{~s}, 3 \mathrm{H}), 2.86(\mathrm{~s}, 6 \mathrm{H}), 4.12(\mathrm{t}, 2 \mathrm{H}, \mathrm{J}=6.0)$, 4.29 (t, 2H, J = 6.0), 5.83-5.84 (m, 3H), 6.88 (d, 1H, J = 2.5), 6.94 (dd, 1H, J = 8.8, 2.5), 7.66 (d, $1 \mathrm{H}, \mathrm{J}=8.8), 7.97(\mathrm{~b}, 1 \mathrm{H})$. MS (ESI), $\mathrm{m} / \mathrm{z}$ calcd for $\mathrm{C}_{22} \mathrm{H}_{25} \mathrm{NO}_{5}$ : 383.4. Found: $384.2[\mathrm{M}+\mathrm{H}]^{+}$.

7-\{[4-(3-Dimethylamino-5-hydroxyphenoxy)butoxy] $\}$-3,4-dimethyl-2H-chromen-2-one (21). ${ }^{1} \mathrm{H}-\mathrm{NMR} \delta$ 1.92-2.01 (m, 4H), $2.18(\mathrm{~s}, 3 \mathrm{H}), 2.37$ (s, 3H), $2.90(\mathrm{~s}, 6 \mathrm{H}), 4.00(\mathrm{t}, 2 \mathrm{H}, \mathrm{J}=5.6), 4.08$ $(\mathrm{t}, 2 \mathrm{H}, \mathrm{J}=6.2), 5.86(\mathrm{~d}, 2 \mathrm{H}, \mathrm{J}=1.9), 5.91(\mathrm{~d}, 1 \mathrm{H}, \mathrm{J}=1.9), 6.82(\mathrm{~s}, 1 \mathrm{H}), 6.85(\mathrm{~d}, 1 \mathrm{H}, \mathrm{J}=2.5)$, $7.48(\mathrm{~d}, 1 \mathrm{H}, \mathrm{J}=8.8), 7.97(\mathrm{~s}, 1 \mathrm{H}) . \mathrm{MS}(\mathrm{ESI}), \mathrm{m} / \mathrm{z}$ calcd for $\mathrm{C}_{23} \mathrm{H}_{27} \mathrm{NO}_{5}$ : 397.5. Found: 398.2 $[\mathrm{M}+\mathrm{H}]^{+}$.

7-(3-\{3-[Benzyl(methyl)amino]-5-hydroxyphenoxy\}propoxy)-3,4-dimethyl-2H-chromen-2-one (22). ${ }^{1} \mathrm{H}-\mathrm{NMR} \delta 2.11(\mathrm{~s}, 3 \mathrm{H}), 2.21(\mathrm{qn}, 2 \mathrm{H}, \mathrm{J}=6.2), 2.39(\mathrm{~s}, 3 \mathrm{H}), 2.98(\mathrm{~s}, 3 \mathrm{H}), 4.09(\mathrm{t}, 2 \mathrm{H}, \mathrm{J}=$ 6.2), $4.25(\mathrm{t}, 2 \mathrm{H}, \mathrm{J}=6.2), 4.50(\mathrm{~s}, 2 \mathrm{H}), 5.84-5.85(\mathrm{~m}, 1 \mathrm{H}), 5.87-5.88(\mathrm{~m}, 2 \mathrm{H}), 6.86(\mathrm{~d}, 1 \mathrm{H}, \mathrm{J}=$ 2.5), $6.92(\mathrm{dd}, 1 \mathrm{H}, \mathrm{J}=8.8,2.5), 7.21-7.33(\mathrm{~m}, 5 \mathrm{H}), 7.65$ (d, 1H, J = 8.8), 7.98 (s, 1H). MS (ESI), $\mathrm{m} / \mathrm{z}$ calcd for $\mathrm{C}_{28} \mathrm{H}_{29} \mathrm{NO}_{5}$ : 459.5. Found: $460.3[\mathrm{M}+\mathrm{H}]^{+}$.

7-(4-\{3-[Benzyl(methyl)amino]-5-hydroxyphenoxy\}butoxy)-3,4-dimethyl-2H-chromen-2-one (23). ${ }^{1} \mathrm{H}-\mathrm{NMR} \delta$ 1.86-1.96 (m, 4H), 2.11 (s, 3H), 2.39 (s, 3H), 2.98 (s, 3H), 3.97 (t, 2H, J = 6.0), $4.16(\mathrm{t}, 2 \mathrm{H}, \mathrm{J}=6.0), 4.50(\mathrm{~s}, 2 \mathrm{H}), 5.83(\mathrm{~d}, 1 \mathrm{H}, \mathrm{J}=1.9), 5.86(\mathrm{~d}, 2 \mathrm{H}, \mathrm{J}=1.9), 6.84(\mathrm{~d}, 1 \mathrm{H}, \mathrm{J}=$ 2.5), $6.91(\mathrm{dd}, 1 \mathrm{H}, \mathrm{J}=8.8,2.5), 7.21-7.33(\mathrm{~m}, 5 \mathrm{H}), 7.64(\mathrm{~d}, 1 \mathrm{H}, \mathrm{J}=8.8), 7.96(\mathrm{~s}, 1 \mathrm{H})$. MS (ESI), $\mathrm{m} / \mathrm{z}$ calcd for $\mathrm{C}_{29} \mathrm{H}_{31} \mathrm{NO}_{5}$ : 473.5. Found: $474.2[\mathrm{M}+\mathrm{H}]^{+}$.

\section{Preparation of methylammonium quaternary salts (24-27)}

The symmetrical dimethylaminoresorcinol derivatives 14 and 15, and the coumarin derivatives 20 and 21 were dissolved in $\mathrm{CH}_{3} \mathrm{CN}$ and treated with 20 equivalent of $\mathrm{CH}_{3} \mathrm{I}$ at reflux for 20 hours. The solvent was removed under vacuum to afford the methylammonium quaternary salts 24-27, that were treated with anh. ethyl ether and $\mathrm{CH}_{2} \mathrm{Cl}_{2}$ to remove unreacted starting materials. The compounds so obtained were sufficiently poor and, without further purifications, are currently under screening as $\mathrm{AChE}$ and BChE inhibitors.

3-Hydroxy-5-\{3-[3-hydroxy-5-(trimethylammonio)phenoxy]propoxy\}- $N, N, N$-trimethylbenzenaminium diiodide (24). ${ }^{1} \mathrm{H}-\mathrm{NMR}\left(\mathrm{DMSO}_{\mathrm{d}}\right) \delta 2.17-2.19(\mathrm{~m}, 2 \mathrm{H}), 3.50(\mathrm{~s}, 18 \mathrm{H}), 4.13$ $(\mathrm{t}, 4 \mathrm{H}, \mathrm{J}=6.0), 6.50(\mathrm{~s}, 2 \mathrm{H}), 6.82(\mathrm{~s}, 2 \mathrm{H}), 6.94(\mathrm{~s}, 2 \mathrm{H}), 10.30(\mathrm{~s}, 2 \mathrm{H})$.

3-Hydroxy-5-\{4-[3-hydroxy-5-(trimethylammonio)phenoxy]butoxy\}- $N, N, N$-trimethylbenzenaminium diiodide (25). ${ }^{1} \mathrm{H}-\mathrm{NMR}\left(\mathrm{DMSO}_{-} \mathrm{d}_{6}\right) \delta 1.85(\mathrm{~b}, 4 \mathrm{H}), 3.50(\mathrm{~s}, 18 \mathrm{H}), 4.04$ (b, 4H), $6.50(\mathrm{~s}, 2 \mathrm{H}), 6.80(\mathrm{~s}, 2 \mathrm{H}), 6.92(\mathrm{~s}, 2 \mathrm{H}), 10.26(\mathrm{~s}, 2 \mathrm{H})$.

3-\{3-[(3,4-Dimethyl-2-oxo-2H-chromen-7-yl)oxy]propoxy\}-5-hydroxy- $N, N, N$-trimethyl-

benzenaminium iodide (26). ${ }^{1} \mathrm{H}-\mathrm{NMR}\left(\mathrm{DMSO}_{\mathrm{d}} \mathrm{d}_{6}\right) \delta 2.06(\mathrm{~s}, 3 \mathrm{H}), 2.19(\mathrm{t}, 2 \mathrm{H}, \mathrm{J}=6.2), 2.35(\mathrm{~s}$, $3 \mathrm{H}), 3.50(\mathrm{~s}, 9 \mathrm{H}), 4.15(\mathrm{t}, 2 \mathrm{H}, \mathrm{J}=6.2), 4.22(\mathrm{t}, 2 \mathrm{H}, \mathrm{J}=6.2), 6.52(\mathrm{~m}, 1 \mathrm{H}), 6.81(\mathrm{~m}, 1 \mathrm{H}), 6.93(\mathrm{~d}$, $1 \mathrm{H}, \mathrm{J}=2.5), 6.96(\mathrm{~s}, 2 \mathrm{H}), 7.68(\mathrm{~d}, 1 \mathrm{H}, \mathrm{J}=8.6), 10.26(\mathrm{~s}, 1 \mathrm{H})$. 
3-\{4-[(3,4-Dimethyl-2-oxo-2H-chromen-7-yl)oxy]butoxy\}-5-hydroxy- $N, N, N$-trimethylbenzenaminium iodide (27). ${ }^{1} \mathrm{H}-\mathrm{NMR}\left(\mathrm{DMSO}_{-} \mathrm{d}_{6}\right) \delta 1.87(\mathrm{~b}, 4 \mathrm{H}), 2.06(\mathrm{~s}, 3 \mathrm{H}), 2.35(\mathrm{~s}, 3 \mathrm{H})$, $3.50(\mathrm{~s}, 9 \mathrm{H}), 4.04(\mathrm{~b}, 2 \mathrm{H}), 4.09-4.15(\mathrm{~m}, 2 \mathrm{H}), 6.49(\mathrm{~s}, 1 \mathrm{H}), 6.80(\mathrm{~s}, 1 \mathrm{H}), 6.91(\mathrm{~d}, 1 \mathrm{H}, \mathrm{J}=2.5)$, $6.94(\mathrm{~s}, 2 \mathrm{H}), 7.68(\mathrm{~d}, 1 \mathrm{H}, \mathrm{J}=8.5), 10.27(\mathrm{~s}, 1 \mathrm{H})$.

\section{Acknowledgements}

The authors gratefully acknowledge the financial support of the University of Bari (Italy) and of the Italian Ministry for Education, Universities and Research (MIUR, Rome, Italy). Thanks are due to the student Leonardo Pisani for his valuable technical contribution in the synthesis of the chemical library outlined in Scheme 6.

\section{References}

1. Ganesan, A. Drug Discovery Today 2002, 7, 47.

2. (a) Thompson, L. A.; Ellman, J. A. Chem. Rev. 1996, 96, 555. (b) Nefzi, A.; Ostresh, J. M.; Houghten, R. A. Chem. Rev. 1997, 97, 449. (c) Bunin, B. A.; Dener, J. M.; Livingston, D. A. Ann. Rep. Med. Chem. 1999, 34, 267. (d) Franzén, R. G. J. Comb. Chem. 2000, 2, 195.

3. Dolle, R. E. J. Comb. Chem. 2002, 4, 369.

4. (a) Watson, C. Angew. Chem., Int. Ed. 1999, 38, 1903. (b) Brown, A. R.; Hermkens, P. H. H.; Ottenheijm, H. C. J.; Rees, D. C. Synlett 1998, 6, 817. (c) Brown, R. C. D. J. Chem. Soc., Perkin Trans. 1 1998, 3293. (d) Booth, S.; Hermkens, P. H. H.; Ottenheijm, H. C. J.; Rees, D. C. Tetrahedron 1998, 54, 15385.

5. Baldino, C. M. J. Comb. Chem. 2000, 2, 89.

6. Shuttleworth, S. J.; Allin, S. M.; Sharma, P. K. Synthesis 1997, 11, 1217.

7. (a) Booth, R. J.; Hodges, J. C. Acc. Chem. Res. 1999, 32, 18. (b) Flynn, D. L. Med. Res. Rev. 1999, 19, 408. (c) Parlow, J. J.; Devraj, R. V.; South, M. S. Curr. Opin. Chem. Biol. 1999, 3, 320.

8. Merrifield, R. B. J. Am. Chem. Soc. 1963, 85, 2149.

9. (a) Bunin, B. A.; Ellman, J. A. J. Am. Chem. Soc. 1992, 114, 10997. (b) Bunin, B. A.; Plunkett, M. J.; Ellman, J. A. Proc. Natl. Acad. Sci. USA 1994, 91, 4708.

10. Barnard, E. A. The peripheral nervous system; Hubbard, J. I., Ed.; Plenum Press: New York 1974; pp 2001-224.

11. Jacobsen, J. S. Curr. Top. Med. Chem. 2002, 2, 343.

12. Hardy, J.; Selkoe, D. J. Science 2002, 297, 353.

13. Gnerre, C.; Catto, M.; Leonetti, F.; Weber, P.; Carrupt, P. A.; Altomare, C.; Carotti, A.; Testa, B. J. Med. Chem. 2000, 43, 4747.

14. Wang, S.-S. J. Am. Chem. Soc. 1973, 95, 1328. 
15. Petrzilka, T.; Lusuardi, W. G. Helv. Chim. Acta 1973, 56, 510.

16. Hughes, D. L. Org. Prep. Proc. Int. 1996, 28, 127.

17. Israelstam, S. S.; Barris, E. Chemistry and Industry 1958, 1430.

18. Piazzi, L.; Rampa, A.; Bisi, A.; Gobbi, S.; Belluti, F.; Cavalli, A.; Bartolini, M.; Andrisano, V.; Valenti, P.; Recanatini, M. J. Med. Chem. 2003, 46, 2279. 